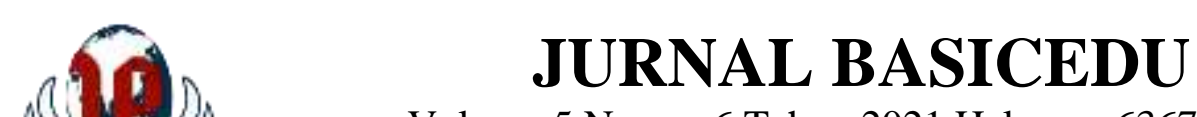

Volume 5 Nomor 6 Tahun 2021 Halaman 6367 - 6377

Research \& Learning in Elementary Education

https://jbasic.org/index.php/basicedu

PAHLATANA

\title{
Desain Pembelajaran Berbasis Mathematical Cognition Topik Mengenal Bilangan untuk Siswa Lamban Belajar di Sekolah Dasar
}

\author{
Wita Tri Yanti ${ }^{1 凶}$, Ahmad Fauzan ${ }^{2}$ \\ Universitas Negeri Padang, Indonesia ${ }^{1,2}$ \\ E-mail: witatriyanti@gmail.com ${ }^{1}$, ahmadfauzan@fmipa.unp.ac.id ${ }^{2}$
}

\begin{abstract}
Abstrak
Penelitian ini dilatarbelakangi oleh beberapa permasalaha yang ditemui pada awal penelitian. Hasil studi literatur dan studi pendahuluan menyatakan bahwa, Pembelajaran matematika di SD sangatlah penting terutama topik mengenal bilangan. Ditemukan adanya siswa SD yang dikategorikan lamban belajar kemampuan kepakaan bilangan masih rendah. Oleh sebab itu dirancanglah LIT berbasis Mathematical Cognition yang valid, praktis dan efektif. Jenis penelitian yang digunakan developmental research approach dengan menggunakan Design research yang dikemukakan Gravemeijer \& Cobb. Subjek uji coba yaitu siswa lamban belajar di Sekolah Dasar 06/III Ambai Atas. Penelitian didukung dengan teknik pengumpulan data berupa analisis dokumen, observasi, wawancara, angket, dan tes. Analisis data dilakukan statistik deskritif. Hasil validi HLT menunjukkan LIT valid yang terlihat dari aspek isi, bahasa didaktik dan penyajian yang sesuai dengan dengan prinsip yang terlihat dari segi kemudahan dalam penggunaan. Keterbacaan siswa dan ketersediaan waktu sehingga siswa lamban belajar dapat melakukan serangkaian aktivitas belajar LIT. LIT berdampak pada kemampuan kepekaan siswa terhadap bilangan. Hal ini terlihat dari kemampuan awal siswa sebelum diberikan intervensi setelah siswa mendapatkan intervensi terlihat adanya perubahan.
\end{abstract}

Kata Kunci: desain pembelajaran, mathematical cognition, siswa lamban belajar, sekolah dasar

\begin{abstract}
This research is motivated by several problems encountered at the beginning of the study. The results of the literature study and preliminary studies state that Mathematics learning in elementary training is mainly about recognizing numbers. It was found that there were elementary school students who were categorized as slow to learn, but the ability to use numbers was still low. Therefore, a valid, practical, and effective LIT based on Mathematical Cognition was designed. The type of research used is a developmental research approach using Design research proposed by Gravemeijer \& Cobb. The subject of the experiment is slow learners at Elementary School 06/III Ambai Atas. The research was supported by data collection in the form of document analysis, observation, interviews, questionnaires, and tests. Data analysis was carried out by descriptive statistics. The results of the HLT validity show that the LIT is valid as seen from the aspect of content, didactic language, and presentation in accordance with the principles seen in terms of ease of use. Readability of students and availability of time so that students learn to do LIT learning activities. LIT has an impact on students' ability to number. This can be seen from the initial ability of students before being given an intervention, after getting the intervention, there was a change.
\end{abstract}

Keywords: learning design, mathematical cognition, slow learners, elementary school

Copyright (c) 2021 Wita Tri Yanti, Ahmad Fauzan

Corresponding author :

Email : witatriyanti@gmail.com

DOI : https://doi.org/10.31004/basicedu.v5i6.1728

ISSN 2580-3735 (Media Cetak)

ISSN 2580-1147 (Media Online)

Jurnal Basicedu Vol 5 No 6 Tahun 2021

p-ISSN 2580-3735 e-ISSN 2580-1147 
6368 Desain Pembelajaran Berbasis Mathematical Cognition Topik Mengenal Bilangan untuk Siswa Lamban Belajar di Sekolah Dasar - Wita Tri Yanti, Ahmad Fauzan

DOI: https://doi.org/10.31004/basicedu.v5i6.1728

\section{PENDAHULUAN}

Pembelajaran matematika merupakan bagian dari salah satu ilmu pengetahuan yang sangat penting. Dalam kehidupan sehari-hari, matematika sangat banyak memiliki peranan penting. Salah satu peranan matematika dalam kehidupan sehari-hari yaitu sebagai alat penyampai informasi, informasi tersebut disampaikan dengan bahasa matematika dan meningkatkan kemampuan berfikir secara sistematis, kritis serta daya kreatifitas menjadi meningkat. Pembelajaran matematika yang banyak kontribusi dalam kehidupan seharihari, maka diperlukan pembelajaran matematika sejak dini kepada siswa (Ediyanto, Gistituati, Fitria, \& Zikri, 2020).

Pembelajaran matematika di Sekolah Dasar (SD) merupakan dasar dalam siswa untuk mengetahui konsep matematika. Tujuan pembelajaran matematika di SD yaitu siswa harus mampu memecahkan masalah secara sistematik. Permasalahan yang diselesaikan siswa SD berkaitan dengan kehidupan nyata. Tujuan utama pembelajaran matematika disekolah yaitu agar siswa dapat memiliki kemampuan matematis yang baik untuk dapat menyelesaikan masalah dalam kehidupan sehari-hari. Selanjutnya dalam kurikulum 2013 menyatakan bahwa tujuan pembelajaran matematika yaitu siswa mampu memahami konsep dan menerapkan prosedur matematika dalam kehidupan sehari-hari (Ahmad Fauzan \& Yerizon, 2013).

Mengingat pentingnya pembelajaran matematika dan tujuan pembelajaran matematika SD yaitu supaya siswa dapat menerapkan kemampuan matematis dalam kehidupan sehari-hari. Maka diperlukan pemahaman konsep yang baik dan memadai di SD pada setiap topik yang dipelajari. Salah satu topik pembelajaran matematika yang sangat penting yaitu mengenal bilangan 0-99 bagi siswa SD pada awal pembelajaran matematika (Diba, Zulkardi, \& Saleh, 2009). Mengenal bilangan merupakan konsep dasar dalam mempelajari matematika di SD, dimana konsep dasar mengenal bilangan akan menjadikan siswa selanjutnya dapat memahami pembelajaran matematika dengan baik (Ekowati, Kusumaningtyas, \& Sulistyani, 2017).

Konsep bilangan digunakan siswa dalam pembelajaran matematika yang berkaitan dengan pencacahan dan pengukuran. Bilangan merupakan suatu sebutan yang digunakan untuk menyatakan jumlah/banyak sesuatu (Husen, Anggraeni, \& Sari, 2019). Kepekaan bilangan merupakan hal yang harus dimiliki oleh setiap siswa di SD. Sebagaimana di ungkapkan bahwa unsur yang paling penting dalam pembelajaran matematika di SD yaitu mengembangkan kepekaan bilangan (Li \& Yang, 2010).

Namun kenyataanya di lapangan berdasarkan hasil observasi yang dilakukan penulis di SDN 06/III Ambai Atas Kecamatan Sitinjau Laut, Kabupaten Kerinci di pada tangal 6 januari 2021 ditemukan bahwa siswa yang memiliki kemampuan kepekaan biangan yang sangat rendah. Hal ini dilihat bahwa siswa tersebut masih belum mampu membedakan mana yang lebih banyak antara 8 dan 9 . Siswa tersebut membutuhkan waktu yang banyak untuk menjawab dan penjelasan yang berulang dari guru. Hal ini sejalan dengan mengukapkan bahwa kepekaan serta konsep bilangan yang dimiliki oleh siswa sangatlah rendah belum sesuai dengan harapan (Whitacre \& Nickerson, n.d.). Permasalahan yang terjadi tersebut juga didukung oleh hasil temuan penelitian terdahulu yang menyatakan bahwa pembelajaran matematika dalam mengenal bilangan bermasalah. Salah satunya penelitian menyebutkan bahwa pencapaian nilai hasil ulangan masih di bawah standar nilai Kriteria Ketuntasan Minimal (KKM) yaitu 70 dan sebanyak 17 siswa dari 28 siswa memperoleh nilai kurang dari 70 dalam pembelajaran mengenal bilangan, hal ini dikarenakan masih minimnya guru menggunakan media pembelajaran, pendekatan pembelajaran serta aktivitas-aktivitas yang disusun atau dirancang oleh guru belum maksimal atau belum memenuhi karakteristik siswa (Dwirahayu \& Nursida, 2016). Sejalan dengan hasil wawancara yang dilakukan penulis dengan guru siswa bahwa guru jarang menggunakan media pembelajaran saat menjelaskan konsep matematika terhadap anak kemudian yang ditemukan penulis yaitu desain pembelajaran atau RPP yang digunakan yaitu pembelajaran yang bisa menuntun siswa lain memahami topik pembahasan, namun untuk siswa yang lamban belajar ini kesulitan dalam mengikuti pembelajaran. 
6369 Desain Pembelajaran Berbasis Mathematical Cognition Topik Mengenal Bilangan untuk Siswa Lamban Belajar di Sekolah Dasar - Wita Tri Yanti, Ahmad Fauzan

DOI: https://doi.org/10.31004/basicedu.v5i6.1728

Studi pendahuluan yang dilakukan peneliti setelah obeservasi yaitu melakukan identifikasi anak berkebutuhan khusus dengan menggunkan instrumen di sekolah pada tanggal 8 dan 9 januari 2021, hasil identifikasi menunjukkan bahwa dari 11 orang siswa kelas 3 SD Negeri 06/III Ambai Atas terdapat siswa yang dikategorikan lamban belajar. Anak yang lamban belajar memiliki ciri-ciri yaitu daya tangkap terhadap pembelajaran amban, sering terlambat menyelsaikan tugas-tugas akademik, rata-rata prestasinya rendaah dan pernah tidak naik kelas (Marlina, 2019). Selanjutnya penulis melakukan asesmen akademik di bidang matematika terhadap siswa yang memiliki ciri-ciri lamban belajar pada tanggal 14 januari 2021 dengan kesimpulan bahwa kemampuan siswa tersebut dalam pembelajaran matematika masih belum dapat menyebutkan bilangan 1-20, kemudian siswa masih belum mengenal lambang bilangan dengan baik, masih belum bisa mengenal makna kuantitas setiap bilangan. Siswa yang berkebutuhan khusus mengalami masalah pada konsep lambang bilangan dan jumlah bendanya (Putra, Hadiyanto, \& Zikri, 2020). Dalam menentukan jumlah benda sesuai dengan lambang bilangannya anak masih sering salah, terutama untuk benda dengan jumlah di atas sepuluh, hal ini dikarenakan guru kurang mampu memiliki kemampuan menerapkan pembelajaran yang bermakna serta pembelajaran yang terpaku pada buku yang digunakan oleh guru. Penelitian selanjutnya menunjukan $29.17 \%$ siswa yang tuntas atau 17 orang siswa dari 24 orang siswa yang kurang mampu menjawab soal-soal yang berkaitan dengan mengenal bilangan, hal ini disebabkan oleh banyaknya anak yang belum mampu mengenal, menuliskan serta mengurutkan lambang bilangan dengan benar (Indah, Anggaini, \& Akina, n.d.).

Dalam proses pembelajaran matematika tentang mengenal bilangan di dalam kelas tentunya ada kesulitan maupun kendala yang terjadi dalam saat proses pemahaman konsep itu terjadi. Salah satu kesulitan dalam memahami konsep mengenal bilangan yaitu anak yang memiliki kemampuan rendah atau kemampuan di bawah rata-rata anak usia atau satu tingkat dengan siswa lainnya. Anak-anak kemampuan rendah tersebut dimaksud di sini yaitu anak dengan kata lain memiliki kendala dalam belajar atau biasa disebut lamban belajar (slow learner) (Hadi, 2014). Lamban belajar merupakan anak yang memiliki prestasi akademik yang rendah tanpa memiliki cacat fisik, Skor tes IQ mereka menunjukkan skor antara 70 dan 90 (Khabibah, 2017). Lamban belajar merupakan salah satu jenis anak berkebutuhan khusus (ABK) yang secara fisik tidak dapat dikendali tapi membutuhkan layanan khusus pada bidang pendidikan yang mana membantu keterbatasan anak tersebut dalam kehidupan sehari-hari (Arini, Choiri, \& Sunardi, 2009). Dalam pembelajaran di kelas anak yang lamban belajar (slow learner) membutuhkan perhatian yang secara khusus untuk memahami materi terutama materi pembelajaran yang begitu abstrak seperti matematika (Rasmitadila \& Boeriswati, 2017).

Kesulitan yang dialami siswa lamban belajar dalam matematika pada awalnya berkisar pada penguasaan dalam konsep mengenal bilangan serta empat operasi dasar yaitu penjumlahan, pengurangan, perkalian, dan penjumlahan (Kroesbergen, Van de Rijt, \& Van Luit, 2007). Kemudian, berdasarkan penelitian yang dilakukan oleh (A. Fauzan, Armiati, \& Ceria, 2018) yang menyatakan bahwa terdapat 5\% sampai 8\% siswa SD yang memiliki masalah dengan kemampuan kognitif mereka terkait dengan konsep atau prosedur di dalam matematika. Penelitian lain juga menemukan sekitar 5-6\% siswa mengalami kesulitan yang signifikan dalam matematika dan kebanyakan dari mereka tidak teridentifikasi sejak awal sebagai siswa yang memerlukan perhatian khusus dalam pelajaran matematika sampai sekolah menengah (Kroesbergen et al., 2007). Hal ini mengakibatkan jika tidak ditangani sejak awal kelemahan memahami konsep bilangan siswa SD sejak awal maka akan semakin membuat mereka mengalami kesulitan belajar matematika yang lebih tinggi lagi ditingkatkan sekolah selanjutnya. Terutama bagi anak-anak yang memang memiliki kemampuan berpikir rendah.

Dari pemaparan hasil observasi, hasil wawancara, hasil identifikasi, hasil asesmen serta studi literatur yang dilakukan penulis, seharusnya siswa yang seusia dan setingkat kelas dengan siswa tersebut sudah harus memahami konsep mengenal bilangan Sesuai dengan tuntutan kurikulum yang berlaku yaitu kurikulum 2013 dimana anak SD di kelas 3 sudah mampu menggunakan dan mengaplikasikan bilangan yang akan diterapkan 
6370 Desain Pembelajaran Berbasis Mathematical Cognition Topik Mengenal Bilangan untuk Siswa Lamban Belajar di Sekolah Dasar - Wita Tri Yanti, Ahmad Fauzan

DOI: https://doi.org/10.31004/basicedu.v5i6.1728

siswa dalam operasi penjumlahan, pengurangan, perkalian serta pembagian. Hal ini yang menjadi permasalahan bagi siswa tersebut karena tidak mampu untuk memenuhi tuntutan kurikulum sedangkan dilihat dari seri perkembangan baik usia dan mental, siswa tersebut harusnya sudah mampu memenuhi tuntutan kurikulum (Ningsih, Miaz, \& Zikri, 2019).

Penyebab permasalahan yang dipaparkan di atas salah satunya yaitu proses kegiatan pembelajaran yang belum efektif yang diberikan guru kelas terhadap anak yang lamban belajar (slow learmer). Guru pada umumnya menggunkakan metode ceramah dalam melaksanakan proses pembelajaran (Ahmad Fauzan \& Yerizon, 2013). Hal tersebut mengakibatkan anak mengalami kesulitan dalam belajar terutama anak yang memiliki kemampuan rendah untuk memahami materi konsep-konsep pembelajaran matematika.

Permasalahan-permasalahan yang dipaparkan di atas diperlukan solusi untuk mengatasinya, diperlukan desain pembelajaran yang matang yang harus disiapkan seorang guru untuk mengatasi hal tersebut. Namun kenyataan ditemukan masih banyak guru yang membuat desain pembelajaran yang tidak tepatdan sesuai dengan siswa lamban belajar. Penelitian selanjutnya menyatakan bahwa guru medesain pembelajaran di dalam kelas hanya secara keseluruhan siswa untuk mencapai target kurikulum yang sudah ditetakan tanpa memperhatikan kebutuhan-kebutuhan bagi siswa lamban belajar yang terdapat di kelas tersebut (Barnard et al., 2018).

Guru harus mampu memahami kendala anak yang lamban belajar. Apabila guru membiarkan, tentunya akan berakibat buruk kepada siswa, terutama siswa yang lamban belajar (slow learner) maka siswa tersebut akan semakin ketinggalan pengetahuan yang dimilikinya dibandingkan anak seusia dan setingkat kelas dengannya (Kurnia \& Nurhayati, 2020).

Salah satu solusi yaitu mengembangkan dan merancang aktivitas-aktivitas pembelajaran yang relevan mengarahkan siswa yang lamban belajar secara tepat dan mudah untuk memahami konsep mengenal bilangan (A Fauzan \& Yezita, 2016). Pengembangan aktivitas-aktivitas pembelajaran tantunya harus mempertimbangkan siswa tersebut salah satunya yaitu keadaan, kesukaan siswa tersebut supaya mempermudah anak untuk memahami konsep mengenal bilangan (A. Fauzan et al., 2018).

Aktivitas pembelajaran yang dirancang diharapkan nantinya dapat membuat siswa lamban belajar dapat memahami konsep matematika. Dalam proses tersebut siswa lamban belajar mengalami proses pemahaman mendeskripsikan dan memecahkan masalah kontekstual dengan mengembangkan strategi informalnya dalam bahasa atau konsep matematika. Salah satu pembelajaran yang sesuai dengan aktivitas-aktivitas tersebut yaitu dengan pendekatan Mathematical Cognition.

Mathematical Cognition merupakan studi pemprosesan kogintif siswa dalam aspek angka dan matematika. Pada proses ini mental dan struktur yang terlibat dalam penalaran dan pemikiran tentang angka dan matematika, serta tentang memecahkan masalah aritmatika (Ashcraft \& Guillaume, 2009). Mathematical Cognition didedikasikan untuk memahami bentuk-bentuk yang sederhana seperti seri dan perhitungan dalam matematika. Sehingga dengan Mathematical Cognition ini siswa memiliki number sense, number relation dan number construction yang menuntun siswa untuk lebih peka terhadap bilangan dan mempunyai kemampuan penalaran numerik yang tinggi (Grodd \& Chassy, 2016). Fokusnya terutama pada efek ukuran masalah, tolak ukur efek pengetahuan seseorang tersebut, karena pusatnya ke pengguna teoritis dari proses kognitif dalam aritmatika, dan karena pengaruh yang diberikannya ketika kita mempertimbangkan aspek lain dari pemprosesan, misalnya peran memori kerja dalam pemrosesan matematika (Grodd \& Chassy, 2016).

Dengan memperhatikan hakikat dari Mathematical Cognition, maka guru dituntut untuk memetakan kemungkinan siswa menemukan suatu konsep mengenal bilangan. Guru diharapkan dapat memberikan aktivitas-aktivitas yang menunjang terjadinya proses penemuan sehingga siswa mampu membangun pengetahuannya. Melalui penelitian ini akan dikembangkan suatu produk yang disebut dengan Local Instructional Theory (LIT). LIT merupakan teori tentang proses pembelajaran untuk suatu topik tertentu dengan aktivitas yang mendukungnya (Gravemeijer, 1994). LIT yang dikembangkan disesuaikan dengan memperhatikan prinsip dan karakteristik Mathematical Cognition. Topik yang digunakan berkaitan dengan 
mengenal bilangan untuk anak lamban belajar di SD. Bentuk Awal produk yang dikembangkan yaitu Hypotetical Learning Trajectory (HLT) dan di dukung oleh Rancangan Pelaksanaan Pembelajaran (RPP) dan Lembar Kerja Siswa (LKPD) sebagai sarana penunjang proses pembelajaran.

HLT berkaitan dengan aktivitas guru membayangkan bagaimana cara berpikir dan belajar siswanya pada suatu topik pembelajaran. Hal ini seperti yang dijelaskan (Fahrurozi, Maesaroh, Suwanto, \& Nursyahidah, 2018) bahwa HLT merupakan dugaan peneliti atau guru terhadap kemungkinan alur pembelajaran yang terjadi di kelas pada saat merancang pembelajaran. Alur pembelajaran yang dimaksud merupakan gambaran pemikiran yang dilakukan siswa pada rute yang terkait dengan domain matematika untuk memunculkan proses mental dengan maksud mendukung pencapaian tujuan khusus pada domain matematika tersebut. Ada tiga komponen yang terdapat pada HLT, seperti yang diungkapkan (Simon \& Tzur, 2004) yakni tujuan belajar siswa, kegiatan belajar yang akan dialami siswa, dan hipotesis tentang proses siswa selama belajar. Tiga komponen tersebut dilengkapi dengan antisipasi yang akan dilakukan guru terhadap hipotesis mengenai kekeliruan yang dilakukan siswa.

\section{METODE}

Jenis penelitian yaitu penelitian pengembangan (developmental research approach). Pengembangan dilakukan untuk menghasilkan produk berupa Local Instructional Theory (LIT) topik menggenal Bilangan dengan bentuk awal produk berupa Hypothetical Learning Trajectory (HLT) dan didukung RPP dan LKPD. Pengembangan produk tersebut menggunakan design research tipe Gravemeijer and Cobb (2013). Desain penelitian ini terdiri dari tiga fase, yakni preparing for the experiment, experimenting in the classroom, dan conducting retrospective analyses (Ahmad Fauzan \& Yerizon, 2013)(Fahrurozi et al., 2018).

Desain ini digunakan untuk mengembangkan LIT dengan bentuk awal berupa HLT. Untuk membuat HLT, kegiatan diawali dengan thought experiment yaitu memikirkan alur pembelajaran yang akan dilalui siswa dan kemudian melakukan refleksi terhadap hasil eksperimen yang dilakukan. Jika tujuan belum tercapai maka dilanjutkan dengan thought experiment dan instruction experiment berikutnya dengan materi yang sama, sehingga LIT memandu thought experiment dan instruction experiment (Ediyanto et al., 2020).

\section{HASIL DAN PEMBAHASAN}

\section{Hasil Self Evaluation}

Produk yang dihasilkan melalui self evaluation terlebih dahulu. Hal ini dilakukan untuk mengurangi kesalahan yang dibuat saat merancang produk. Adapun hal yang direvisi ialah kesalahan pengetikan, penyajian gambar, dan kalimat. Berdasarkan hal tersebut, berikut hasil self evaluation yang dilakukan terhadap produk yang dirancang pada tabel 1 .

\section{Tabel 1}

Hasil Self Evaluation Produk

\begin{tabular}{llll}
\hline No & Aspek yang Dievaluasi & Sebelum Revisi & Sesudah Revisi \\
\hline 1. & Kesalahan pengetikan & HLT & HLT \\
& & $\bullet$ Dengankan & $\bullet$ Dengarkan \\
& & $\bullet$ Binngung & $\bullet$ bingung \\
& & $\bullet$ Menyelsaikan & $\bullet$ menyelesaikan \\
& & $\bullet$ Bigung & $\bullet$ bingung \\
& & & $\bullet$ bekerjasama \\
\hline $2 \quad$ Kesalahan penulisan bahasa & RPP & RPP \\
& asing & $\bullet$ menyelsaikan & $\bullet$ Menyelesaikan \\
& & $\bullet$ apakah & $\bullet$ Apakah \\
& & LKPD & LKPD \\
& & $\bullet$ diatas & $\bullet$ di atas \\
& & $\bullet$ ananda & Ananda \\
\hline
\end{tabular}


6372 Desain Pembelajaran Berbasis Mathematical Cognition Topik Mengenal Bilangan untuk Siswa Lamban Belajar di Sekolah Dasar - Wita Tri Yanti, Ahmad Fauzan

DOI: https://doi.org/10.31004/basicedu.v5i6.1728

\begin{tabular}{|c|c|c|c|}
\hline & & $\begin{array}{l}\text { HLT } \\
\text { - Probing question } \\
\text { RPP } \\
\text { - Sanse }\end{array}$ & $\begin{array}{l}\text { HLT } \\
\text { - Probing question } \\
\text { RPP } \\
\text { - sense }\end{array}$ \\
\hline 3 & Ketepatan ukuran tulisan & $\begin{array}{l}\text { LKS } \\
\text { - Ukuran judul LKS 1, 2, 3, dan } \\
4 \text { berbeda serta penulisan } \\
\text { aktivitas kecil (12) }\end{array}$ & $\begin{array}{l}\text { LKS } \\
\text { - Ukuran judul LKS 1, 2, 3, } \\
\text { dan } 4 \text { serta penulisan } \\
\text { aktivitas diperbesar (16) }\end{array}$ \\
\hline 4 & $\begin{array}{l}\text { Ketersediaan tempat jawaban } \\
\text { untuk menyelesaikan } \\
\text { masalah yang diberikan }\end{array}$ & $\begin{array}{l}\text { LKS } \\
\text { - Baris-baris yang disediakan } \\
\text { kurang memadai dan tidak } \\
\text { teratur }\end{array}$ & $\begin{array}{l}\text { LKS } \\
\text { - Baris-baris yang disediakan } \\
\text { dibuat memadai dan teratur }\end{array}$ \\
\hline
\end{tabular}

\section{Hasil Expert Review}

Validasi dilakukan oleh 5 orang pakar terhadap produk yang telah dibuat yaitu 2 orang dosem matematika, 1 orang dosen bahasa, 1 orang dosen seni, 1 orang guru sekolah dasar.Instrumen validasi HLT terlebih dahulu divalidasi melalui lembar validasi oleh validator. Hasil validasi oleh dua validator menunjukan bahwa instrument yang digunakan untuk memvalidasi HLT ialah sangat valid dengan nilai rata-rata 86. Hal ini dapat dilihat pada lampiran. Penilaian validasi HLT terdiri dari aspek isi dan aspek bahasa. Hasil validasi aspek isi kedua validator menunjukkan nilai 87,8 dengan kategori sangat valid. Rincian hasil validasi aspek isi dapat dilihat pada tabel 2 .

Tabel 2

Hasil Validasi HLT

\begin{tabular}{llll}
\hline No. & Aspek yang Dinilai & Rata-rataValiditas & Kriteria \\
\hline 1. & Isi & 88 & Sangat Valid \\
\hline 2. & Bahasa & 89 & Sangat Valid \\
\hline Nilai & ValidasiHLT & 87,8 & Sangat Valid \\
\hline
\end{tabular}

Berdasarkan kedua aspek yang dinilai dari dua validator, rata-rata penilaian HLT menunjukkan rata-rata 87,8 dengan kategori validitas yaitu sangat valid pada lampiran 8 dan 9. Sementara itu, hasil validasi yang telah dilakukan, terdapat beberapa masukan yang diberikan oleh validator. Adapun perbandingan HLT sebelum dan sesudah revisi ialah sebagai berikut.

Tabel 3

Perbandingan HLT Sebelum dan Sesudah Revisi

\begin{tabular}{llll}
\hline No & Validator & Sebelum Revisi & Sesudah Revisi \\
\hline 1. & Isi & $\begin{array}{l}\text { Prediksi yang digunakan belum } \\
\text { mampu memprediksi } \\
\text { kemungkinan secara rinci dan } \\
\text { hanya mampu memprediksi } \\
\text { secara umum saja. }\end{array}$ & $\begin{array}{l}\text { Prediksi yang digunakan } \\
\text { sudah mampu memprediksi } \\
\text { kemungkinan secara rinci. }\end{array}$ \\
& & $\begin{array}{l}\text { Prediksi dari segi penulisan dan } \\
\text { kata sapaan perlu diperbaiki. }\end{array}$ & $\begin{array}{l}\text { Prediksi dari segi penulisan } \\
\text { dan kata sapaan sudah } \\
\text { diperbaiki. }\end{array}$ \\
\hline 2. & Bahasa & & \\
& &
\end{tabular}

Validasi RPP dilakukan dengan memvalidasi instrument validasi dan RPP yang telah dibuat. Hasil lembar validasi menunjukan bahwa instrument yang digunakan untyuk mengukur kevalidan RPP memiliki nilai ratarata 84 (lampiran 10 dan 11). Dengan instrument yang memiliki kategori sangat valid, maka hasil validasi RPP yang dilakukan menunjukan nilai rata-rata 81, 3 dengan kategori sangat valid (lampiran 12 dan 13). Kategori tersebut terlihat pada aspek yang dinilai yakni aspek komponen RPP dan kegiatan pembelajaran. Adapun rincian dari kedua aspek tersebut, seperti pada tabel 4. 
6373 Desain Pembelajaran Berbasis Mathematical Cognition Topik Mengenal Bilangan untuk Siswa Lamban Belajar di Sekolah Dasar - Wita Tri Yanti, Ahmad Fauzan

DOI: https://doi.org/10.31004/basicedu.v5i6.1728

Tabel 4

Perbandingan RPP Sebelum dan Sesudah Revisi

\begin{tabular}{llll}
\hline No & Aspek yang Dinilai & Nilai & Validitas \\
\hline 1 & Komponen pembelajaran & 82 & Sangat valid \\
\hline 2 & Kegiatan pembelajaran & 80 & valid \\
\hline
\end{tabular}

Berdasarkan validasi yang telah dilakukan, terdapat beberapa masukan yang diberikan oleh validator Adapun perbandingan RPP sebelum dan sesudah revisi ialah sebagai berikut.

Tabel 5

Perbandingan RPP Sebelum dan Sesudah Revisi

\begin{tabular}{llll}
\hline No & Validator & Sebelum Revisi & Sesudah Revisi \\
\hline 1. & Isi & Langkah-langkah menggambarkan & Langkah-langkah menggambarkan \\
& & kegiatan guru. & kegiatan siswa. \\
& & $\begin{array}{l}\text { Contoh : } \\
\text { Guru bersama siswa melakukan tanya } \\
\text { jawab mengenai permasalahan tersebut. }\end{array}$ & $\begin{array}{l}\text { Siswa bersama guru melakukan } \\
\text { Tanya jawab mengenai } \\
\text { permasalahan tersebut. }\end{array}$ \\
& & $\begin{array}{l}\text { Langkah pembelajaran diarahkan pada } \\
\text { kegiatan guru. }\end{array}$ & $\begin{array}{l}\text { Langkah pelajaran diarahkan pada } \\
\text { kegiatan siswa. }\end{array}$ \\
\hline 2. & Bahasa & &
\end{tabular}

Instrument validasi LKPD terlebih dahulu divalidasi melalui lembar validasi oleh validator. Hasil validasi oleh 2 validator menunjukan bahwa instrument yang digunakan memiliki kategori sangat valid dengan nilai rata-rata 84 . Sementara itu, hasil validasi LKPD menunjukan kategori sangat valid dengan nilai rata-rata 81. Adapun aspek yang dinilai ialah aspek didaktik, isi, bahasa, dan penyajian dengan rincian nilai seperti tabel 6 .

Tabel 6

Hasil Validasi LKPD

\begin{tabular}{llll}
\hline No & Aspek yang Dinilai & Nilai & Validitas \\
\hline 1 & Didaktik & 88 & Sangat Valid \\
\hline 2 & Isi & 88 & Sangat Valid \\
\hline 3 & Bahasa & 87 & Sangat Valid \\
\hline 4 & Penyajian & 91 & Valid \\
\hline & Rata-rata & 81 & Sangat Valid \\
\hline
\end{tabular}

Berdasarkan validasi yang telah dilakukan, terdapat beberapa masukan yang diberikan oleh validator. Adapun perbandingan LKPD sebelum dan sesudah revisi ialah sebagai berikut.

Tabel 7

Perbandingan LKPD Sebelum dan Sesudah Revisi

\begin{tabular}{llll}
\hline No & Validator & Sebelum Revisi & Sesudah Revisi \\
\hline 1. & Isi & $\begin{array}{l}\text { Masalah yang diberikan } \\
\text { terlalu mudah }\end{array}$ & $\begin{array}{l}\text { Masalah yang diberikan } \\
\text { disesuaikan dengan karakteristik } \\
\text { siswa lamban belajar }\end{array}$ \\
\hline 2. & Bahasa & Huruf berukuran 14 & Huruf berukuran 16. \\
\hline 3. & Kegrafikan & $\begin{array}{l}\text { Ukuran huruf disesuaikan } \\
\text { dengan kriteria LKPD }\end{array}$ & Ukuran huruf sudah disesuaikan \\
\hline & & $\begin{array}{l}\text { Jenis tulisannya } \\
\text { diperhatikan }\end{array}$ & $\begin{array}{l}\text { Jenis tulisannya sudah } \\
\text { diperbaiki }\end{array}$ \\
\hline
\end{tabular}

\section{Pembahasan}

Hasil expert review terhadap produk yang dirancang menunjukan produk layak digunakan. Produk utama (HLT) mengandung validitas isi dan bahasa yang layak. Dalam aspek isi, HLT mengandung tujuan 
6374 Desain Pembelajaran Berbasis Mathematical Cognition Topik Mengenal Bilangan untuk Siswa Lamban Belajar di Sekolah Dasar - Wita Tri Yanti, Ahmad Fauzan

DOI: https://doi.org/10.31004/basicedu.v5i6.1728

pembelajaran aktivitas siswa dan dugaan proses belajar/berpikir siswa. Hal ini sesuai yang pernyataan (A Fauzan \& Yezita, 2016) bahwa HLT memiliki tiga komponen, yakni tujuan belajar siswa, kegiatan belajar yang akan dialami siswa, dan hipotesis tentang proses siswa selama pembelajaran. Tujuan yang dimaksudkan ialah pencapaian pemahaman konsep matematika. Kemudian, kegiatan belajar berkaitan dengan serangkaian tugas untuk mengetahui cara berpikir siswa. Aktivitas pembelajaran yang terjadi dijadikan sebagai temuan yang nantinya akan dijadikan LIT. sebagaimana definisi LIT yang diungkapkan oleh (Gravemeijer, 1994) bahwa LIT merupakan teori tentang proses pembelajaran untuk suatu topik tertentu dengan aktivitas yang mendukung.

Aktivitas setiap pertemuan mengarahkan kepada siswa lamban belajar untuk mengungkapkan proses berifikir siswa. HLT dijadikan sebagai dugaan alur belajar yang akan terjadi di setiap pertemuan. Prediksi dan antisipasi yang di buat akan ada yang muncul dan juga tidak muncul. HLT mengadung prinsip pengembangan model mandiri menjamati siswa dalam bernalar. Semua aktivitas memiliki peran untuk mendorng siswa dalam memiki kepekaan dalam bilangan, hal ini didasarkan dari pendekatan yang digunakan, yakni Mathematical Cognition.

Dalam mendesain pembelajaran berbasis Mathematical Cognition, peneliti memperhatikan perinsip utama Mathematical Cognition. Pembelajaran berbasis Mathematical Cognition menekankan pada proses berfikir siswa. Melalui pengalaman dan ekspolar yang diberikan guru dan lingkungan dari pengalaman tersebut akan menimbulkan kepekaan.

Aspek isi HLT yang layak didukung oleh aspek bahasa yang layak. Dalam aspek bahasa, HLT memiliki kebenaran tata bahasa. Kalimat sederhana sesuai dengan tingkat berpikir siswa. Struktur kalimat sesuai dengan tingkat penguasaan bahasa siswa. Selain itu, HLT memiliki kejelasan arahan dan petunjuk.

Berdasarkan HLT yang telah valid, sehingga produk pendukung, yakni RPP dan LKPD yang berpedoman pada HLT juga memiliki kelayakan untuk digunakan. Hal ini terlihat pada hasil validitas RPP dan LKPD.

Pada validitas RPP, terdapat dua aspek yang dinilai, yakni aspek komponen RPP dan kegiatan pembelajaran. Kelayakan dari komponen RPP terlihat pada identitas mata pelajaran yang ditulis lengkap, penjabaran tujuan pembelajaran yang sesuai dengan kompetensi dasar dan indikator, waktu yang dialokasikan, metode pembelajaran, kegiatan yang dirancang, sumber belajar, dan instrument penilaian yang efektif. Sementara itu, kelayakan dari kegiatan pembelajaran terlihat pada langkah-langkah pembelajaran yang digunakan sesuai dengan prinsip Mathematical Cognition. Kegiatan pembelajaran dirancang dengan dapat memfasilitasi siswa untuk mengkontruksi pengetahuan sendiri.

Pada validitas LKPD, terdapat empat aspek yang dinilai, yakni aspek didaktik, isi, bahasa, dan penyajian. Kelayakan dari aspek didaktik terlihat penyajiaan masalah konstektual dalam aktivitas LKPD dan kegiatan memecahkan masalah yang terdapat pada LKPD. Kelayakan dari aspek isi terrlihat dari komponen LKPD, gambar yang disajikan, dan soal-soal yang disajikan. Kelayakan dari aspek bahasa terlihat dari penggunaan kalimat yang sesuai dengan kaidah bahasa Indonesia dan kemampuan berbahasa siswa lamban belajar, serta struktur kalimat yang jelas dan tidak menimbulkan kerancuan. Selain itu, kelayakan dari aspek penyajian terlihat dari cover, gambar, dan pemilihan jenis dan ukuran huruf.

Kevalidan dari produk yang dirancang, seperti HLT, RPP, dan LKPD didukung dengan saran-saran yang diberikan oleh validator. Produk direvisi dengan berpedoman terhadap saran yang dimiliki. Saran tersebut menjadikan produk yang dirancang lebih baik, seperti perbandingan produk sebelum dan sesudah revisi yang telah dipaparkan pada hasil penelitian

Uji coba dilakukan dengan satu siswa lamban belajar, terdapat temuan penting ketika uji coba. Ada lima pertemuan yang dilakukan selama uji coba. Pertemuan pertama menemukan makna bilangan0-9, pertemuan kedua menemukan makna bilangan 0-9 dengan lebih banyak dan lebih sedikit, pertemuan ketiga menemukan makna bilangan ganjil dan genap dari bilangan 0-9, pertemuan ke empat menemukan makna lambang bilangan 0-9, pertemuan kelima menemukan makna lambang bilangan dngan lebih besar dan lebih kecil. Setiap pertemuan dilakukan pengamatan terhadap pembelajaran yang dilakukan, apakah prediksi dan antisipasi yang 
6375 Desain Pembelajaran Berbasis Mathematical Cognition Topik Mengenal Bilangan untuk Siswa Lamban Belajar di Sekolah Dasar - Wita Tri Yanti, Ahmad Fauzan

DOI: https://doi.org/10.31004/basicedu.v5i6.1728

di buat pada HLT apakah muncul hal tersebut pada pemikiran siswa atau belum. Jika muncul apakah antisipasi berupa pertanyaan pemicu yang kita berikan sudah optimal apa belum dalam membantu siswa untuk menemukan penyelesaian yang diharapkan setiap pertemuannya. Jika belum lakukan evaluasi untuk dilaksanakan pada pertemuan berikutnya. Namun jika ada prediksi yang baru atau tidak terprediksi sebelumnya harus kita masukan pada HLT dan di buat juga antisipasi jika prediksi muncul pada waktu pertemuan berikutnya. Begitu seterusnya selama kelima pertemuan.

Kepraktisan produk yang ditemukan memperkuat temuan peneliti terdahulu, seperti (Simon \& Tzur, 2004)mengungkapkan bahwa kepratisan produk berbasis Mathematical Cognition ditandai dengan pembelajaran yang menuntut siswa untuk bernalar, mengeluarkan pendapat serta proses berfikir siswa dalam menemukanjawaban. Produk yang berbasis Mathematical Cognition praktis digunakan dan cukup mudah untuk diterapkan pada siswa lamban belajar. Aktivitas belajar yang dirancang berguna untuk memimpin siswa menuju tujuan yang diharapkan. Hal ini tentunya tidak terlepas dari bimbingan guru dengan melakukan kegiatan mengajar yang tepat.

Keefektifan produk dilihat dari hasil test yang diberikan kepada siswa yang terdapat dalam LKPD. Hasil test yang berkaitan dengan kepekaan bilangan siswa. Perbandingan hasil belajar dilihat dari kondisi awal siswa dengan hasil test yang diberikan kepada siswa setelah diberikan intervensi atau perlakuan yaitu berupa desain pembelajaran berbasis Mathematical Cognition. Dari hasil perbandingan fase yang dilalui siswa dapat dikatakan bahwa desain pembelajaran berbasis Mathematical cognition efektif meningkatkan kemampuan siswa dalam kepekaan bilangan.

\section{KESIMPULAN}

Penelitian ini merupakan penelitian pengembangan yang menghassilkan LIT topik mengenal bilangan berbasis Mathematical Cognition. Berdasarkan hasil penelitian dan pembahasan yang telah dilakukan, diperoleh kesimpulan sebagai berikut: 1)LIT yang dihasilkan memiliki kategori yang sangat valid. Hal ini mengabarkan bahwa produk yang dikembangkan memiliki karakteristik mulai dari aspek isi, bahasa, didaktik, dan penyajian yang sesuai dengan prinsip dan karakteristik mathematical cognition sehingga layak diterapkan dalam pembelajaran mengenal bilangan paada siswa lamban belajar di Sekolah Dasar. 2) LIT yang dihasilkan memiliki kategori praktis. Hasil ini menunjukkan bahwa LIT memiliki karakteristik praktis dari segi kemudahan penggunaan, keterbacaan siswa dan ketersediaan waktu siswa lamban belajar. 3) LIT yang dihasilkan memiliki kategori efektif. Hasil yang menunjukkan bahwa LIT memiliki karakteristik efektif terhadap kemampuan bernalar siswa lamban belajar. 4) LIT bebasis Mathematical Cognition yang dihasilkan, mampu membawa siswa lamban belajar menemukan makna bilangan 0-9, kuantitas bilangan, serta lambang bilangan.

\section{DAFTAR PUSTAKA}

Arini, F. D., Choiri, A. S., \& Sunardi, S. (2009). Chapter 4 Mathematical Cognition and the Problem Size Effect. Psychology of Learning and Motivation. Advances in Research and Theory, 51.

Ashcraft, M. H., \& Guillaume, M. M. (2009). Chapter 4 Mathematical Cognition and the Problem Size Effect. Psychology of Learning and Motivation - Advances in Research and Theory (Vol. 51). https://doi.org/10.1016/S0079-7421(09)51004-3

Barnard, L., Lan, W. Y., Crooks, S. M., Alexiou, A., Paraskeva, F., Bempechat, J., ... Champakaew, W. (2018). Educational Psychology in Practice : theory, research and practice in educational psychology The impact of different teaching methods on students ' arithmetic and self - regulated learning skills. Learning and Instruction, 7(2), 37-41. https://doi.org/10.1108/ITSE-10-2017-0050

Diba, F., Zulkardi, Z., \& Saleh, T. (2009). Pengembangan Materi Pembelajaran Bilangan Berdasarkan Pendidikan Matematika Realistik Untuk Siswa Kelas V Sekolah Dasar. Jurnal Pendidikan Matematika, $3(1)$. 
6376 Desain Pembelajaran Berbasis Mathematical Cognition Topik Mengenal Bilangan untuk Siswa Lamban Belajar di Sekolah Dasar - Wita Tri Yanti, Ahmad Fauzan

DOI: https://doi.org/10.31004/basicedu.v5i6.1728

Dwirahayu, G., \& Nursida. (2016). Mengembangkan pembelajaran matematika dengan menggunakan metode permainan untuk siswa kelas 1 MI. Jurnal Matematika Dan Pendidikan Matematika, 5(2), 117-138. https://doi.org/10.33387/dpi.v5i2.177

Ediyanto, E., Gistituati, N., Fitria, Y., \& Zikri, A. (2020). Pengaruh Pendekatan Realistic Mathematics Education Terhadap Motivasi Dan Hasil Belajar Materi Matematika Di Sekolah Dasar. Jurnal Basicedu, 4(1), 203-209. https://doi.org/10.31004/basicedu.v4i1.325

Ekowati, D. W., Kusumaningtyas, D. I., \& Sulistyani, N. (2017). Ethnomathematica Dalam Pembelajaran Matematika (Pembelajaran Bilangan Dengan Media Batik Madura, Tari Khas Trenggal Dan Tari Khas Madura). Jurnal Pemikiran Dan Pengembangan Sekolah Dasar (JP2SD), 5(2), 716. https://doi.org/10.22219/jp2sd.vol5.no2.716-721

Fahrurozi, A., Maesaroh, S., Suwanto, I., \& Nursyahidah, F. (2018). Developing Learning Trajectory Based Instruction of the Congruence for Ninth Grade Using Central Java Historical Building. JRAMathEdu (Journal of Research and Advances in Mathematics Education), 3(2), 78. https://doi.org/10.23917/jramathedu.v3i2.6616

Fauzan, A., Armiati, A., \& Ceria, C. (2018). A Learning Trajectory for Teaching Social Arithmetic using RME Approach. IOP Conference Series: Materials Science and Engineering, 335(1). https://doi.org/10.1088/1757-899X/335/1/012121

Fauzan, A, \& Yezita, E. (2016). Pengembangan Alur Belajar Topik Perbandingan dengan Pendekatan RME. Prosiding Konaspi VIII Di Jakarta Tahun 2016.

Fauzan, Ahmad, \& Yerizon. (2013). Pengaruh Pendekatan RME dan Kemandirian Belajar Terhadap Kemamampuan Matematis Siswa. Prosiding Semirata FMIPA Universitas Lampung, 7-14.

Gravemeijer, K. P. (1994). Developing realistic Mathematics Education (Ontwikkelen van realistisch reken/wiskundeonderwijs).

Grodd, W., \& Chassy, P. (2016). Abstract Mathematical Cognition. Lausanne: Frontiers in Human Neuroscience. https://doi.org/10.3389/978-2-88919-816-0

Hadi, F. R. (2014). Analisis Proses Pembelajaran Matematika Pada Anak Berkebutuhan Khusus (Abk) Slow Learners Di Kelas Inklusi (Penelitian Dilakukan di SD Al Firdaus Surakarta). UNS (Sebelas Maret University).

Husen, S. D., Anggraeni, F., \& Sari, R. (2019). Penggunaan Media Kartu Angka Untuk Peningkatan Kemampuan Pengenalan Numerik Pada Anak Autis. Jurnal Bidang Pendidikan Dasar, 3(2), 15-24.

Indah, I., Anggaini, A., \& Akina, A. (n.d.). Peningkatan Kemampuan Siswa Pada Materi Lambang Bilangan Dengan Menggunakan Kartu Bilangan di Kelas I SDN 2 Kabalutan Indah, Akina, dan Anggaini. Jurnal Kreatif Online, 4(4).

Khabibah, N. (2017). Penanganan Instruksional Bagi Anak Lambat Belajar (Slow Learner). Didaktika: Jurnal Pemikiran Pendidikan, 19(2), 26-32.

Kroesbergen, E. H., Van de Rijt, B. A. M., \& Van Luit, J. E. H. (2007). Working memory and early mathematics: Possibilities for early identification of mathematics learning disabilities. Advances in Learning and Behavioral Disabilities, 20, 1-19.

Kurnia, R., \& Nurhayati, Y. (2020). Development of Inquiry-Based Student Worksheets (LKPD) on Mathematics Subject in The Material of Cubes and Blocks to Improve Mathematical Understanding of Slow Leaners. PrimaryEdu-Journal of Primary Education, 4(1), 12-27.

Li, M. F., \& Yang, D. (2010). Development and validation of a computer-administered number sense scale for fifth-grade children in Taiwan. School Science and Mathematics, 110(4), 220-230.

Marlina. (2019). Asesmen Kesulitan Belajar (I). Jakarta: Prenada Media Gruop.

Ningsih, S. R., Miaz, Y., \& Zikri, A. (2019). Model Discovery Learning Untuk Meningkatkan Aktivitas Dan 
6377 Desain Pembelajaran Berbasis Mathematical Cognition Topik Mengenal Bilangan untuk Siswa Lamban Belajar di Sekolah Dasar - Wita Tri Yanti, Ahmad Fauzan DOI: https://doi.org/10.31004/basicedu.v5i6.1728

Hasil Belajar Tematik Terpadu Di Sekolah Dasar. Jurnal Basicedu, 3(2), 524-532.

Putra, R. A., Hadiyanto, H., \& Zikri, A. (2020). Pengaruh Model Snowball Throwing Terhadap Hasil Belajar Siswa Kelas V Sekolah Dasar. Jurnal Basicedu, 3(2), 524-532. https://doi.org/10.31004/basicedu.v4i3.416

Rasmitadila, Z., \& Boeriswati, E. (2017). Peers' Instructional Interactions in Inclusive Classrooms: Slow Learner Students and Typical Students. Int. J. of Multidisciplinary and Current Research, 5.

Simon, M. A., \& Tzur, R. (2004). Explicating the role of mathematical tasks in conceptual learning: An elaboration of the hypothetical learning trajectory. Mathematical Thinking and Learning, 6(2), 91-104.

Whitacre, I., \& Nickerson, S. D. (n.d.). Extending a Local Instruction Theory for the Development of Number Sense to Rational Number Preliminary Research Report. 